\title{
ラケットとテニスボールの衝突解析 ${ }^{\dagger}$
}

\section{中 川 紀 壽* 弓 取 正 治** \\ Analysis of Impact between Racket and Tennis Ball}

by

\author{
Noritoshi NaKagawa ${ }^{*}$ and Masaharu YumitorI ${ }^{* *}$
}

In this research, the impact between the racket and the ball was studied experimentally. The behavior of the ball during the impact was analyzed using high speed images. The purpose of this research is to clarify the effect of both impact area and strings tension on the rotational speed and the velocity of ball after impact. The deformation of the ball, the impact time, and the movements of the ball during the impact were studied experimentally. According to the experimental results, the following conclusions can be obtained. It was found that the rotational speed and the velocity after the impact increased with increasing deformation of the strings and decreasing deformation of the ball. Moreover, the rotational speed and the velocity after the impact increased with increasing impact time. And, the rotational speed of the ball after the impact increased with increasing displacement of the ball in the parallel direction to the surface of the strings.

Key words : Tennis ball, Racket, Strings, Impact, High speed camera, Rotational speed

\section{1 緒袞}

現在，テニスは幅広い人に親しまれるスポーツである. そのため, 多くの人が性能の良いラケットを要求するよ うになった。しかし，ラケットの性能評価は使用者の主 観によるため，良いラケットを定義することが難しく， 要求に応じたラケットを短期間で開発することが必要と なってきている。 また, ラケット開発のためには数值シ ミュレーションなどの工学的手法が重要となってきてい るが, ラケットとテニスボールの衝突現象は非常に複雑 であり，その解析が困難である。現在までにボールの反 発やフレーム振動による研究, 1) ボールやラケットの近似 モデルによるシミュレーションなどの研究 ${ }^{2)}$, 3)が行われ ているが, 実際の衝突現象を連続的に詳細に観察したも のはまだ少ないと思われる.

本研究では, 実際にラケットとテニスボールの衝突現 象を高速度カメラで撮影する実験を行った。これまでの

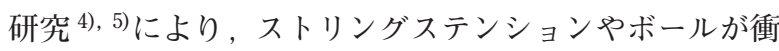
突するストリングス面のエリアの違いによって, 衝突後 のボールの反発・回転特性が変化することがわかってき ている。しかし，その特性の変化がどのような原因で起 こっているかはまだ解明できていなかった。

そこで，今回はその原因を探るためにボールとストリ ングスの衝突中の挙動に注目して実験を行った。ストリ ングステンションやエリアを変化させた時, 衝突中のボー ルとストリングスの変形や衝突時間, ボールの動きなど を観察した。この結果より，ボールの特性に影響を与え る要素について解明することを目的とする.

\section{2 実 験 装 置}

Fig. 1 に実験装置の概略図, Table 1 に実験装置の詳 細を示す。ラケットはストリングス面を地面に対して垂 直に，高速度カメラに対してフレームのトップ部が正面 になるようにフレームを固定し，ストリングス面だけが 変形を起こすようにしている。ラケットの軸とカメラの 光軸は平行である。ラケットのストリングス面に対して 垂直方向にボール発射装置を設置し，また，ストリング ス面の法線に対して $\theta=25^{\circ}$ で目標点にボールを衝突さ せた。なお，撮影速度は $6000 \mathrm{fps}$ (frame per second) で 行った.

今回使用したラケット（全長 700mm，重量 395.09g) を Fig. 2 に示す.フレームの先端部分の一部を切り取 り，その部分を弓状のスチールプレート（長さ $120 \mathrm{~mm}$,

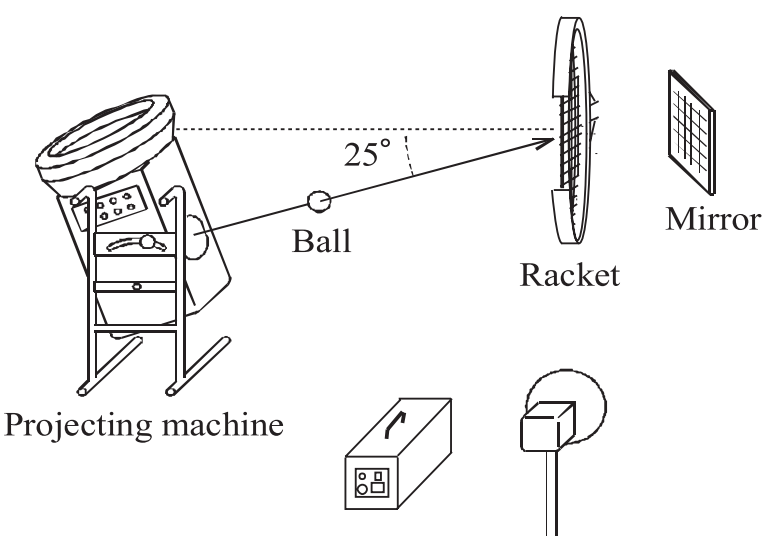

High speed camera Flash unit

$\dagger \quad$ 原稿受理 平成 19 年 8 月 13 日 Received Aug. 13, 2007 C 2008 The Society of Materials Science, Japan

* 正会員 広島大学大学院工学研究科機械システム工学専攻 †739-8527 東広島市鏡山, Mech. System Eng., Graduate School of Eng., Hiroshima Univ., Kagamiyama, Higashi-Hiroshima, 739-8527

** 広島大学大学院 =739-8527 東広島市鏡山, Graduate Student, Hiroshima Univ., Kagamiyama, Higashi-Hiroshima, 739-8527 
Table 1 Details of experimental setup.

\begin{tabular}{|c|c|c|}
\hline Systems & Type & Maker \\
\hline High speed camera & MEMRECAM fxk4 & nac Image Technology \\
\hline Projecting machine & PM20 SH2 & Silver Seiko \\
\hline Tennis racket & RIMBREED Tour-S & Sumitomo Rubber \\
\hline Tennis ball & DUNLOP FORT & Sumitomo Rubber \\
\hline Strings & MICRO SUPER 16 & GOSEM \\
\hline
\end{tabular}

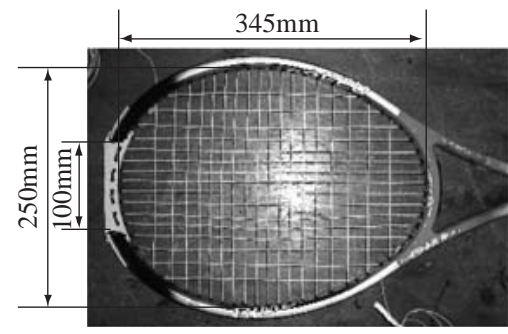

Fig. 2 Modified racket for experiment.

幅 $20 \mathrm{~mm}$, 厚さ $3 \mathrm{~mm}$ ）で作り変えることで, 撮影可能 範囲を $100 \mathrm{~mm}$ 確保した。 この改良により，ストリング ス面に衝突中のボールの挙動をフレームに隠れることな く撮影することができる。 また，ラケットの後方にはス トリングス面に対して $45^{\circ}$ の角度に鏡を設置し，そこに 写るラケット後方から見たボールの様子も同時に撮影し て 3 次元的に解析を行った. Fig. 3 は高速度カメラによ る画像の例である. Fig. 3 (a) はラケットとボールを側方 から見たものであり, Fig. 3 (b) は鏡に写っているボール を後方から見たものである。

この実験装置により，ストリングステンションとボー ルが衝突するストリングスエリアを变化させた時の衝突 中のボールの挙動を調べるために衝突実験を行った. 今 回のストリングスエリアは Fig. 4 に示す 3 つのエリアで 行った。 また, ボールの衝突速度は $9.5 \mathrm{~m} / \mathrm{s}$, 衝突前の回 転数は $0 \mathrm{rps}$ ，ストリングスは太さ $1.30 \mathrm{~mm}$ ，ストリング ステンションは $155.7,200.2,244.7 \mathrm{~N}(35,45,55 \mathrm{lbs})$ の 3 種類を用いた。 ストリングステンションとはラケットに ストリングスを張る時の初張力である。また, 衝突前の 回転数は装置の構造上, ある程度の小さなばらつきはあ るが，ほぼ Orps で発射されており，衝突前の回転による 影響は小さい.

\section{3 衝突後の回転数と速度}

ボールの重心を原点とする座標を考える。ボール上に は予めいくつかのマークをつけておき，そのうち任意の 2 点 $P_{1}, Q_{1}$ が点 $P_{2}, Q_{2}$ に移動したとする。これらの座標

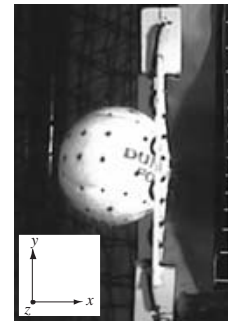

(a) side image

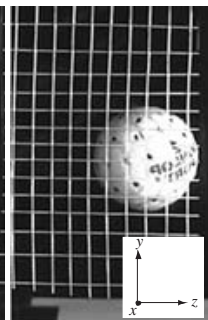

(b) back image

Fig. 3 Image of high speed camera.

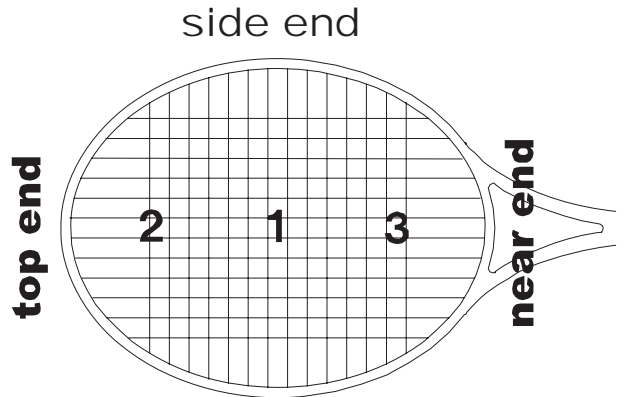

Fig. 4 Areas of strings plane.

值から Fig. 5 のような回転軸と点 $P_{1}$, 回転軸と点 $P_{2}$ を 通る平面 $N_{1}, N_{2}$ を計算により求め，これらの面がなす 角 $\phi$ を求めると回転数 $N \mathrm{rps}$ は，コマ間隔を $\Delta t \mathrm{~s}$ とする と式 (1)で得られる。なお，その間のボールの回転数は 一定であるとする。詳しい方法は前報 ${ }^{5)}$ と同様であるた めに省略する。また, 速度は高速度画像からボールの中 心点の移動を計測して計算により求めた。

$$
N=\frac{\phi}{2 \pi \Delta t}
$$

Fig. 6 に衝突後のボールの回転数の結果を示す。横軸 はエリア, 縦軸は衝突後のボールの回転数を示している. また, Fig. 7 に衝突後のボールの反発速度の結果を示 す。横軸はエリア, 縦軸は衝突後のボールの速度を示し ている.

ストリングステンションを高くすると衝突後の回転数 はどのエリアでも小さくなった．また，エリア 3 での回 転数が最も大きかった，ストリングステンションを高く すると衝突後の速度も全てのエリアで小さくなったが, 回転数よりは変化が小さかった。このように，ボールが 衝突するエリアにより衝突後のボールの特性は異なる. これらの原因を衝突中の挙動から探っていった。

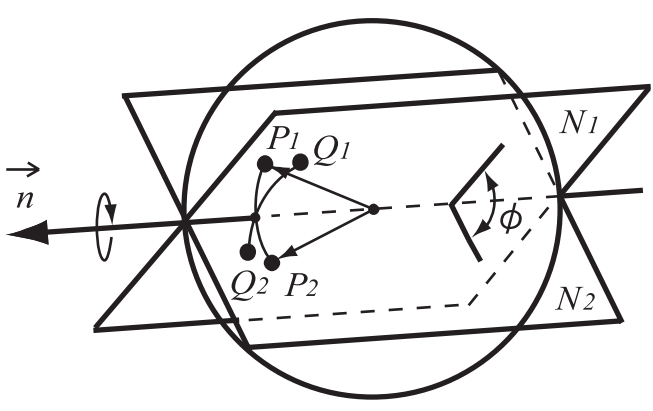

Fig. 5 Angular displacement.

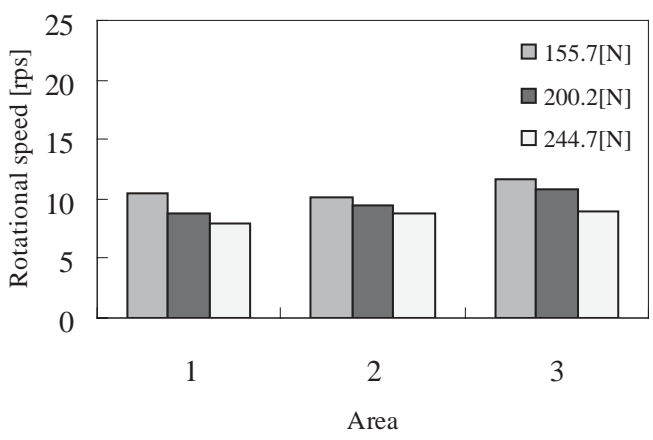

Fig. 6 Rotational speed of ball after impact. 


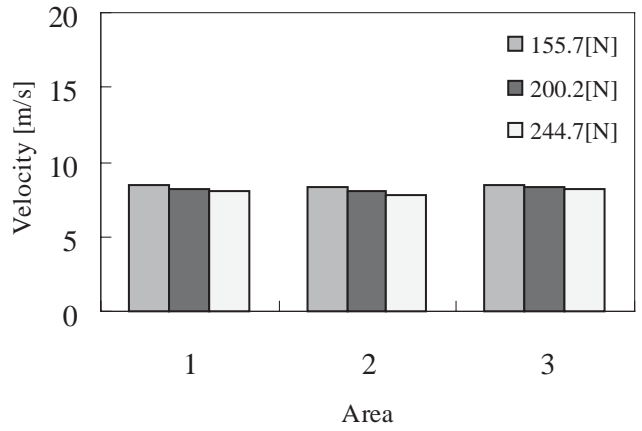

Fig. 7 Velocity of ball after impact.

\section{4 ボールとストリングスの変形}

ストリングステンションとエリアをそれぞれ変化させ た時の衝突中のボールとストリングスの変形を高速度画 像より計測した. Fig. 8 に高速度画像の概略図を示す. Fig. 8 (a)のd は衝突前のボールの直径を示している. また, Fig. 8 (b)の $x$ は衝突中における水平方向のボール の幅であり,$G$ をストリングス面の水平方向の変形とす る。そして， $D$ を水平方向のボールの変形とする。この $G$ と $D$ をそれぞれ衝突開始から終了まで $0.5 \mathrm{~ms}$ ごとに計 測した。

\section{$4 \cdot 1$ ボールの変形過程}

Fig. 9 にエリア 1，2，3 においてストリングステンショ ンを変化させた時の衝突中のボールの変形過程を計測し た結果を示す。横軸は経過時間, 縦軸はボールの変形を 示している.

ボールの水平方向の変形は，どのエリアにおいても衝 突開始から徐々に変形を始めて最大変形に達し, 元の形 に戻る。最大変形に達するまでに要する時間よりも，そ の後に元の形に戻るまでに要する時間のほうが比較的長 いことが多かった。また，ストリングステンションを高 くするとボールの変形過程が早くなり, 最大変形が大き くなった。初張力が大きいためストリングスが変形せず にボールがその影響を受けたと考えられる。また，エリ ア 3 は変形過程が他に比べて早く, ボールの最大変形も 比較的大きかった．エリア 3 はストリングスの端である ため, 変形量が小さかったと考えられる.

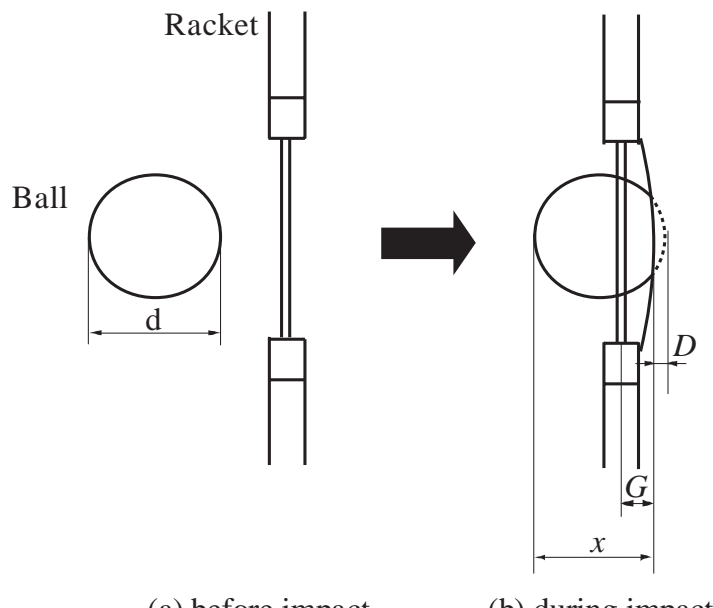

Fig. 8 Schematic illustration of high speed image.

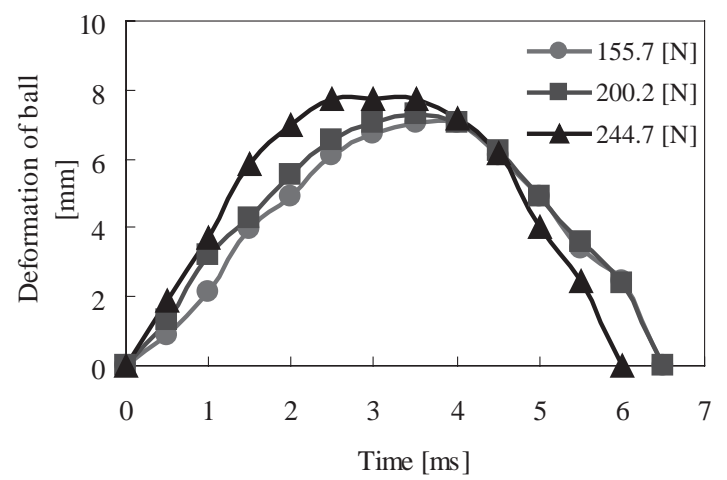

(a) Area 1

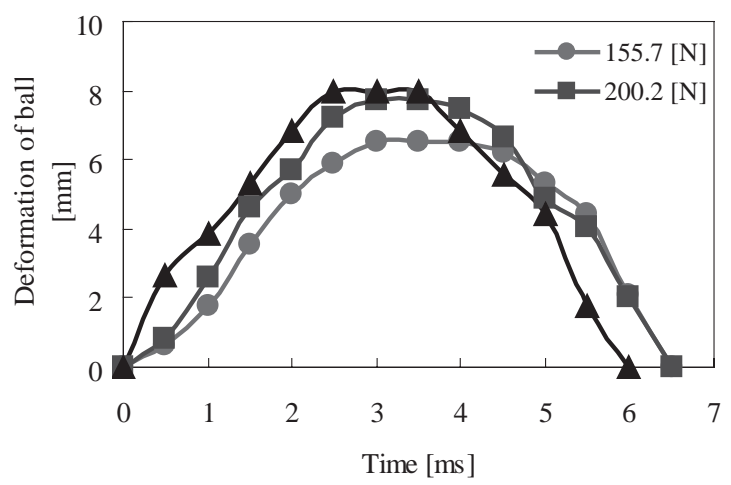

(b) Area 2

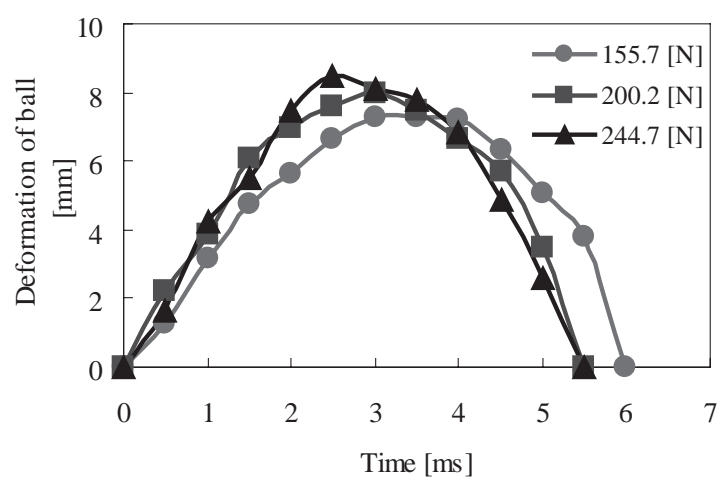

(c) Area 3

Fig. 9 Deformation of ball.

\section{$4 \cdot 2$ ボールの最大変形}

Fig. 10 は Fig. 9 の結果からボールの最大変形をそれ ぞれの条件に対して比較した結果を示している。横軸は エリア，縦軸はボールの最大変形を示している.

ストリングステンションを高くするとボールの最大変 形は大きくなった. Fig. 6, 7 より，ストリングステンショ ンを高くすると衝突後のボールの回転数と速度は小さく なったので衝突中のボールの変形の大きい方が衝突後の ボールの回転数と速度は小さくなりやすいと考えられる. これは, 衝突中にボールの変形が大きくなったことにより 衝突中や衝突後のボールの振動が大きくなりエネルギーが 損失したものと考えられる。また，ボールのすべりによ りエネルギーを損失していることも考えられる。エリア による最大変形の違いは，ストリングス面が変形しくい と考えられるエリア 3 が最も大きい結果であったが，全 体的にはエリアの違いによる差は小さかったため，ボー ルの最大変形がエリア別の特性に与える影響は小さいも のであると考えられる。 


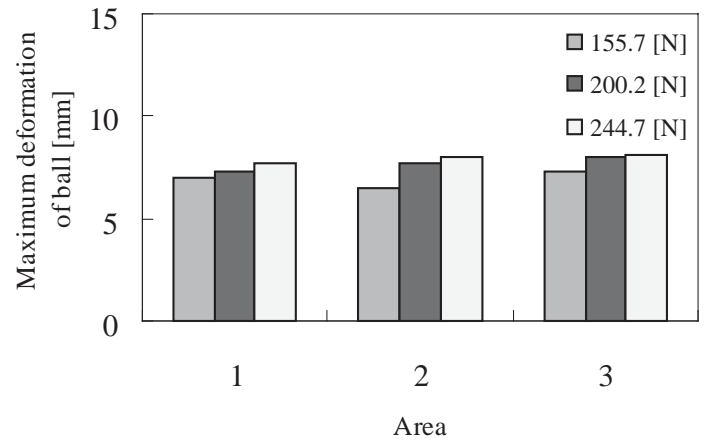

Fig. 10 Maximum deformation of ball.

\section{$4 \cdot 3$ ストリングス面の変形過程}

Fig. 11 はエリア 1，2，3 においてストリングステンショ ンを変化させた時の衝突中のストリングス面の変形過程 の結果を示している。横軸は経過時間, 縦軸はストリン グス面の変形を示している。

ストリングス面の水平方向の変形はボールの変形の場 合と同様にどのエリアにおいても衝突開始から徐々に変 形を始め, 最大変形に達した後に元の形に戻る，最大変 形に達するまでに要する時間とその後に元の形に戻るま でに要する時間はほぼ同じ長さの場合が多かった。また， ストリングステンションを高くするとストリングス面の 変形過程が早くなり，最大変形は小さくなった。この変 化はボールの場合より顕著に現れた。また，エリア 1 と エリア 2 は似たような変形過程の結果を示したのに対し， エリア 3 は変形過程が他のエリアに比べて早く, ストリ ングス面の最大変形が最も小さかった，ストリングスの 端であるため変形が小さいことがわかった。また，エリ ア 2 と 3 は同様な結果になると思われたがフレーム先端 の改良部により，エリア 2 のストリングスが変形しやす くなっているためエリア 1 に近い結果になっていると考 えられる。

\section{$4 \cdot 4$ ストリングス面の最大変形}

Fig. 12 はFig. 11 の結果からストリングスの最大変形 をそれぞれの条件で比較した結果を示している。横軸は エリア，縦軸はストリングスの最大変形を示している.

ストリングステンションを高くするとストリングス面 の最大変形は小さくなった. Fig. 6,7 より, ストリング ステンションを高くすると衝突後のボールの回転数と速 度は小さくなったので衝突中のストリングス面の変形は 大きい方が衝突後にボールの回転数と速度が大きくなり 易いと考えられる。これは, 衝突時にストリングス面の 変形が大きくなったことにより，ボールの変形が抑えら れたこととストリングス面がボールを押し出す反発エネ ルギーが大きくなったためだと考えられる。またエリア別 による最大変形量の違いは，エリア 1 がエリアの中心部 であるためにストリングス面の変形量が大きく，エリア 3 はエリアの端であるためにその面の変形量が小さかったと 思われる。エリア 2 がエリアの端であるにも関わらず変 形量が大きい結果になっているのはラケット先端部の改 良により変形し易くなってしまっているためだと考えら れる，同じエリアではボールの変形が小さく，ストリン グス面の変形量が大きいほど回転数が大きくなり易いが, 回転数が他のエリアより大きいエリア 3 はボールの変形

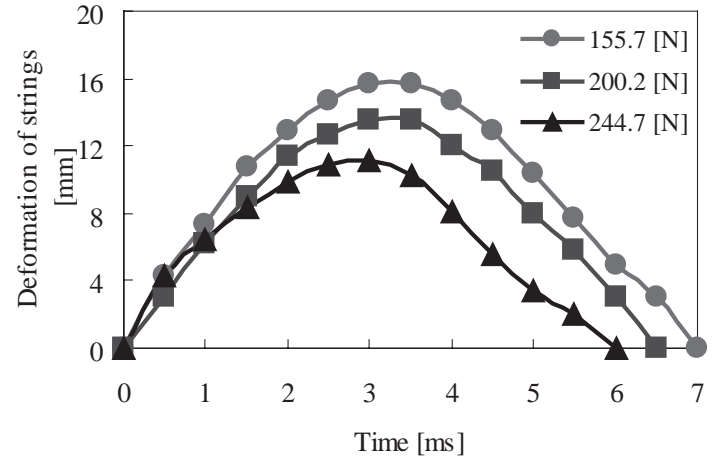

(a) Area 1

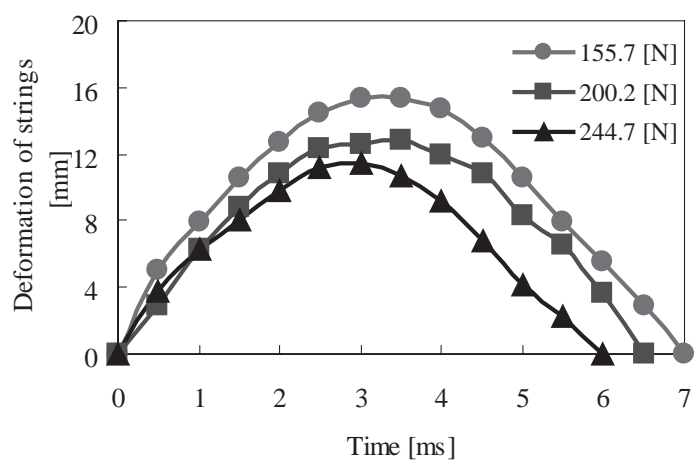

(b) Area 2

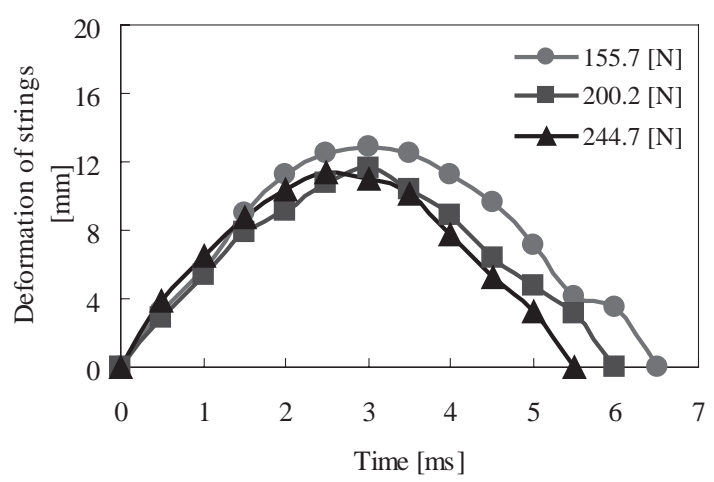

(c) Area 3

Fig. 11 Deformation of strings.

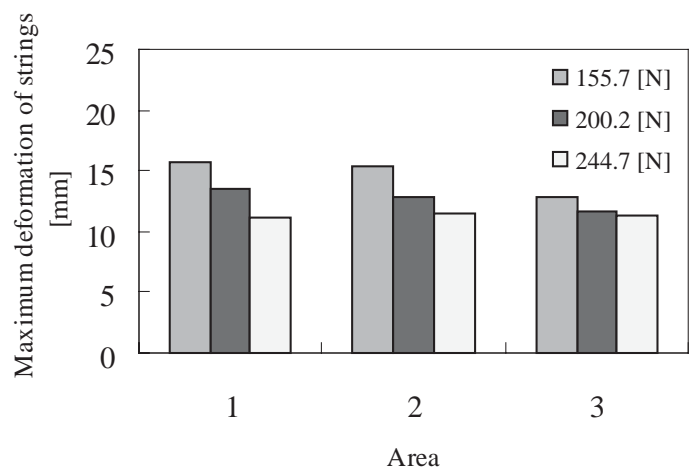

Fig. 12 Maximum deformation of strings.

が大きく，ストリングス面の変形量が小さかった。すな わち，エリアが異なる場合はボールの特性に影響を与え る要素がボールとストリングス面の変形量以外にも存在 すると考えられる．特にエリア 3 はラケットの重心に近 
いエリアであるため，反発エネルギーの大きいことが原 因であると考えられる。

\section{$4 \cdot 5$ 衝突時間}

ボールがストリングス面に接触してから離れるまでの 衝突時間を計測した。Fig. 13 に衝突時間をそれぞれの 条件で比較した結果を示す。横軸はエリア，縦軸は衝突 時間を示している。

ストリングステンションを高くすると衝突時間は短く なった。これはストリングステンションを大きくするこ とによりストリングス面の最大変形が小さくなるため, 衝突時間が短くなったと考えられる。また，Fig. 6, 7 の 結果より，衝突時間が長くなるストリングステンションを 低くした場合においてボールの速度も回転数も大きくなっ ている。すなわち，一般的に衝突時間が長いと回転がか かりやすいと言われるのは，ストリングス面の変形が大き くなりボールとの接触面積が大きくなること，ボールとス トリングス面が長く接することになり，ボールがストリ ングスからより多くのエネルギーを受けるためであると考 えられる．また，エリア別に比較するとストリングス面の 変形が大きいエリア 1 とエリア 2 は比較的衝突時間は長 く，ストリングス面の変形の小さいエリア 3 が短かった. すなわち，衝突時間はストリングス面の変形に影響され ると考えられる。

\section{5 ストリングス面上でのボールの挙動}

\section{$5 \cdot 1$ ボールの動き}

斜めから衝突したボールは衝突中に Fig. 14 (b)に示す ような動きをする．この動きがストリングス面の変形に より変化していると考えられる。そこで, 衝突後のボー

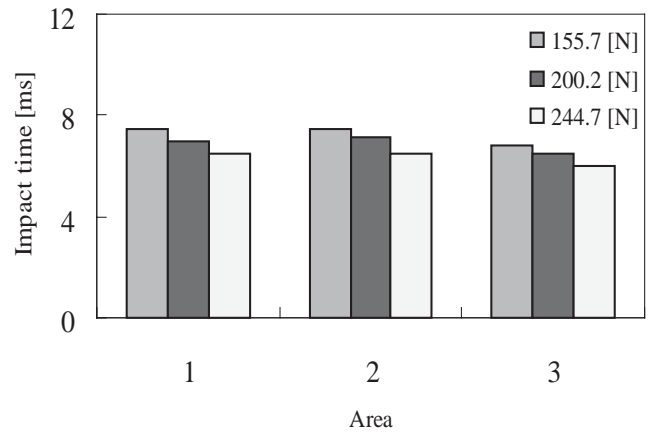

Fig. 13 Impact time.

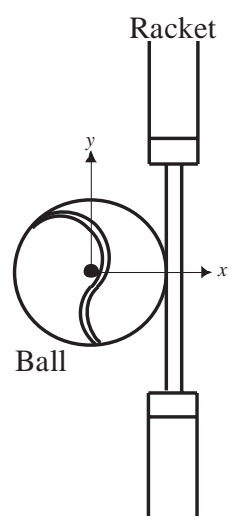

(a) impact

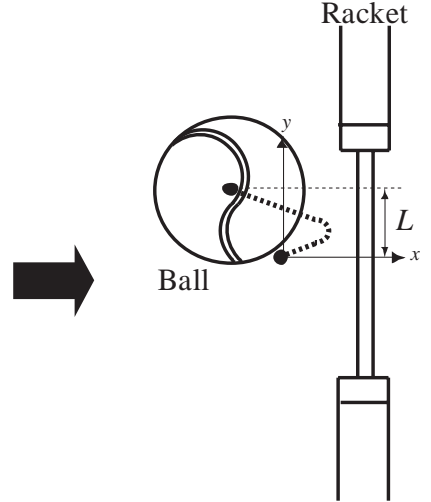

(b) after impact
Fig. 14 Orthogonal coordinates.
ルの回転数に影響する要因を衝突中のボールの動きに注 目してその軌跡を計測することで探っていった。

衝突中のストリングス面上でのボールの動きの軌跡を

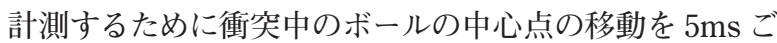
とに計測した。まず，ボールがストリングス面に最初に 接触した際のボールの中心を原点として Fig. 14 (a)のよ うな直交座標を考えた。そして，衝突開始からボールの 中心点の軌跡を計測した。な打，衝突中はボールが変形 するため変形したボール形状の $x$ 方向・ $y$ 方向における 中間点を中心位置とした。

Fig. 15 に衝突中におけるストリングス面上でのボール の中心点の動きを計測して軌跡を描いた結果を示す。横 軸は $x$ 方面の移動距離, 縦軸は $y$ 方面の移動距離を示し ている.

ボールの中心点の動きの軌跡はどのエリアにおいても ストリングステンションを高くすると全てのエリアで $x$ 方 向および $y$ 方向の移動距離が短くなった. $x$ 方向の移動距 離が短くなるのはストリングス面の変形が小さくなったた めだと考えられる。また，ストリングス面の変形が小さ

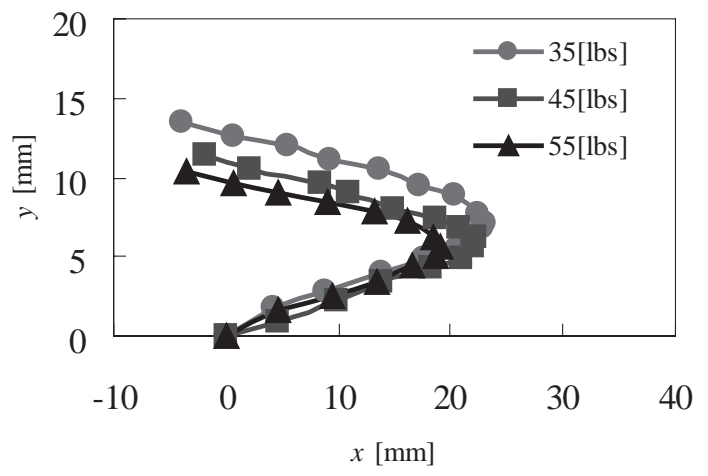

(a) Area 1

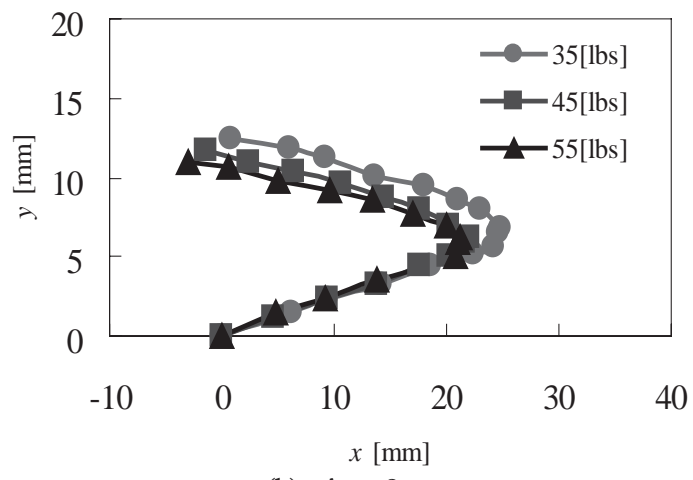

(b) Area 2

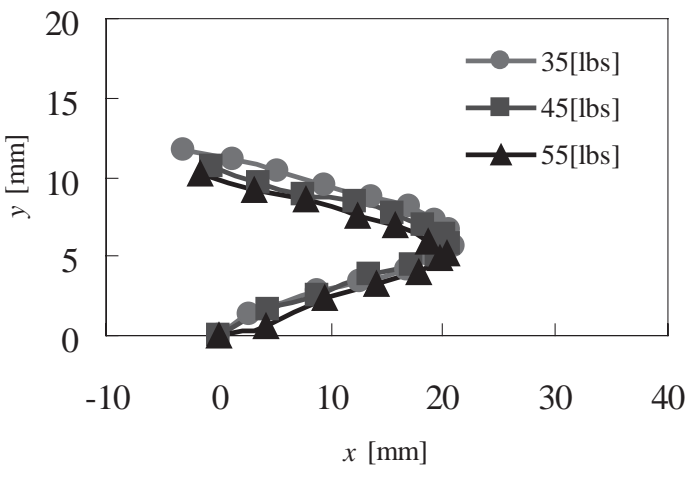

(c) Area 3

Fig. 15 Movements of ball on surface of strings. 
くなるとストリングス面上でのボールの移動距離は $x$ お よび $y$ 方向に短くなった。この $y$ 方向の移動はボールの 回転方向への運動であるボールの転がりであり，衝突後 の回転数に大きく影響していると考えられる。また，ス トリングステンションを変化させても反射角度の変化は 小さかった。

エリア別にみると，エリア 1 と 2 よりもエリア 3 の $x$ 方向の移動距離と $y$ 方向の移動距離が短く, 反射角度も 小さくなった。エリア 3 は Fig. 12 の結果より，ストリ ングス面の変形が小さいために $x$ 方向の移動距離が小さ くなったと考えられる。また，ここでもエリア 2 がエリ ア 1 と似た結果を示したが，実際はもっとエリア 3 のよ うな結果になると考えられる。

\section{$5 \cdot 2$ ボールの $y$ 方向への動き（転がり）}

Fig. 14 の Lで示される $y$ 方向への移動に注目した。 Fig. 16 にストリングステンションとストリングスエリア で比較した結果を示す。横軸はエリア，縦軸は $y$ 方向へ の移動距離を示している.

ストリングステンションを高くすると全てのエリアでy 方向の移動距離は短くなった。 また, Fig. 6,7の結果 よりストリングステンションを高くするほど衝突後の回転 数と速度は小さくなる。すなわち, ストリングステンショ ンを高くすることにより $y$ 方向の移動距離が短くなって 回転数が上昇しにくく，衝突後に回転数が小さくなった と考えられる. また, この $y$ 方向の移動距離がストリン グス面上でのボールの転がりである。ストリングス上で ボールが長く転がることによりストリングスから回転方 向の力を多く受け回転数が大きくなると考えられる。

同じエリアでは転がりの距離が長いほど回転数が大き くなり易いが，回転数が他のエリアより大きいエリア 3 は他のエリアより転がり距離が短かった。つまり，ボー ルが衝突するエリアが異なる場合は転がりの距離だけで はなく，ラケットの重心やボールのすべりなどの反発速 度などの影響があると考えられる。

今回の実験では現象自体をよく観察するために衝突速 度を実際のプレーのものより遅くしているために衝突速 度による差がエリアであまり出なかったと考えられる。今 後, さらに実際のプレーに近い衝突速度での検討が必要 である。

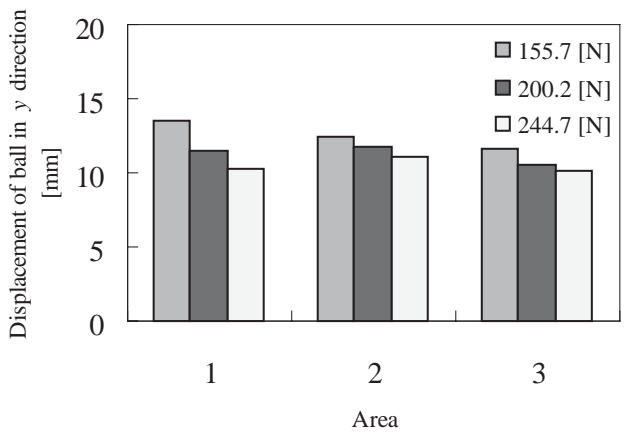

Fig. 16 Displacement of ball in $y$ direction.

\section{6 結言}

本研究ではテニスボールとラケットの衝突中における ボールとストリングスの変形，衝突中のボールの動きに ついて実験的に解析した。

ストリングステンションを高くするとボールの変形は 大きく，ストリングス面の変形は小さくなった。また， エリアの端であるエリア 3 でのストリングスの変形が最 も小さかった。

ストリングステンションを高くすると衝突時間は短く なる。また，ストリングスの変形が小さいエリア 3 で最 も小さかった。

ストリングス面の変形を大きく，ボールの変形を小さく することにより衝突後のボールの回転数は大きくなった. すなわち，ボールが変形によるエネルギーを損失せず， ス トリングス面の変形を大きくしてボールとの接触面積を大 きくしてエネルギーを多く受けることが重要である.

同じエリアでは，ストリングステンションを低くする とボールの $x$ 方向の移動距離だけでなく $y$ 方向の移動距 離も長くなった。これが，ストリングステンションを低 くした時にボールの回転数が大きくなる原因である。つ まり，ボールの $y$ 方向の移動距離（転がり）が長くなる とボールの回転数は大きくなると考えられる.

ストリングスエリアの違いにより，ストリングス面と ボールの変形に違いがある。これが衝突中のボールの $y$ 方向の移動距離（転がり）に影響を与え，その距離が変 化する。これがボールの衝突するエリアで衝突後のボー ルの反発・回転特性が異なる原因であると考えられるが， エリア 3 に扎いてはラケットの重心の影響などその他の 影響も存在すると考えられる。

\section{参 考 文 献}

1) Y. Kawazoe and T. Sakurai, "Effect of Player's Arm on the Rebound Power Coefficient and the Power of a Tennis Racket”, Symposium on Sports Engineering and Symposium on Human Dynamics, pp.207-211 (1999).

2 ) H. Maeda, M. Okauchi and Y. Shimada, "A MODEL OF IMPACT BETWEEN A TENNIS RACKET AND A BALL”, Symposium on Sports Engineering and Symposium on Human Dynamics, pp.35-38 (2000).

3 ) Y. Kanda and M. Takatsuka, "Finite Element Alnalysis of Impact a Ball on a Racket in Tennis (Characteristics of Impact at Off-center of Clamped Strings)", Symposium on Sports Engineering and Symposium on Human Dynamics, pp.31-33 (2000).

4 ) N. Nakagawa, Y. Sekiguchi and N. Okada, "Analysis of Impact between Racket and Ball (Impact Motion of Ball with Spin)”, Symposium on Sports Engineering and Symposium on Human Dynamics, pp.49-53 (2000).

5 ) N. Nakagawa, Y. Sekiguchi and H. Bai, "Analysis of Impact Characteristics of Tennis Ball", The Society of Materials Science, Japan, Vol.55, No.9, pp.807-812 (2006). 